of his never having received any proper training in the rudiments of science. If the appearance of this article serve to call the attention of the managers of our public schools, and cthers interested in education, to the painful consequences which may result from the want of a preliminary grounding in the facts of science and the principles of scientific reasoning-then we think it will not have been written in vain.

\section{THE STORM OF FRIDAY, OCTOBER 14}

THIS great storm, which appeared so suddenly, sped its course over North-Western Europe so rapidly, and involved so wide a region in its destructive violence, will be long remembered for the well-nigh unparalleled loss of human iffe which it has occasioned among our fishing population between the Forth and the Tweed. For some days previously atmospheric pressure had been low to the north of the British Isles and high to the south, the difference from north-west to Land's End being about an inch, thus giving steep gradients, and resulting strong west and north-west winds, and stormy seas along the west coast; and as the area of low pressure moved very slowly eastwards the weather conditions continued with some persistence substantially the same. At length on Thursday morning the daily weather charts showed that a change had just begun in the extreme south-west of Ireland, at Valentia, where, and where only, with a barometer beginning to fall, the wind had changed to a southerly direction, but everywhere else in the British Islands it remained north-westerly; whilst at the same time the area of high pressure to the south was advancing from France to Spain, indicating that the path of the coming storm would take a more southerly course. By 2 p.m. the area of a falling barometer had spread eastwards, and the wind changed to south-west as far as Holyhead; and by $6 \mathrm{p} . \mathrm{m}$. observations showed the continued rapid easterly advance of the storm, the wind being now southerly or south-westerly at all the telegraphic stations except Nairn, where it was west-north-west, showing that Nairn was still within the influence of the slow-moving depression to the nortb.

High winds and very heavy rains occurred during the night over the northern balf of Great Britain, and on Friday morning the weather charts showed that NorthWestern Europe was involved in a storm of great intensity, the centre of which had now advanced as far as Midlothian. Gradients were steep all round the low centre of pressure, and consequently gales and storms of wind prevailed in all parts and in all directions over the British Islands, being west over France and the south of England, south-west and south over the north of England and the North Sea, north-east in the northern half of Scotland, and north-west in Ireland. From the barometric readings published in the Times it is seen that the lowest reading occurred in London about $8 \mathrm{a} . \mathrm{m}$., and, in accordance with the isobars on the Weather Chart, the lowest reading occurred in Edinburgh at the same hour. In London, which was some distance from the centre of the storm, the lowest barometer was only $29^{\circ} 086$ inches, but in Edinburgh, over which the centre passed, pressure fell to 28.425 inches, which was an inch lower than it was twelve hours before. After 8 a.m. a rapid recovery of pressure set in ; the most rapid rise of the barometer in London was 0.214 inch in the two hours from 4 to $6 \mathrm{p.m}$., and 0.163 inch in the two hours immediately following. In Edinburgh the increase proceeded at a much more rapid rate, beginning with $0^{\circ}$ I 8 inch, from 8 to 9 a.m, and increasing gradually to 0.166 inch from noon to I p.m., and $O 150$ inch from I to 2 p.m., after which it rose less rapidly, and continued to do so at a steady, though greatly diminished, rate for two days till Sunday at 10.30 a.m., when the barometer stood at $30^{\circ} 370$ inches, having thus risen nearly two inches in little more than forty-eight hours.

On Saturday morning the centre of the storm had advanced fully 600 miles to eastward, being at the high daily averager of 25 miles an hour, and was now near the south-west angle of Lake Wener in Sweden. Here the lowest barometer was about 28.600 inches, whilst at the same time to westward at Valentia pressure had risen to $30^{\circ} 220$ inches, thus giving for the southern shores of the North Sea steep gradients for north-west winds, which, with the high seas they raised, proved very destructive to those coasts.

The anticyclone indicated by the high barometer following in the wake of the storm was accompanied with temperatures unusually low for the season during the night of Saturday-Sunday, when temperature fell to $27^{\circ} \mathrm{O}$ at Parsonstown and Nottingham; $29^{\circ} \mathrm{O}$ at Ardrossan; and $32^{\circ} \circ$ at Leith, Shields, Cambridge, Oxford, and Mullaghmore. Snowfalls of some depth occurred in many districts, doing no little damage to green crops, and in later districts to grain crops still standing in the fields.

The lamentable destruction to fishing-vessels off the coast of Berwickshire was doubtless to no inconsiderable extent due to the deceptive character of the weather on Friday morning in cases where the barometer either is not consulted, or such a fall as an inch during the twelve hours immediately preceding, is discredited as a precautionary warning. In Midlothian, shortly after eight o'clock, the clouds broke up and the sun shone in a sky rapidly clearing of clouds. Soon, however, a charge commenced, and within an hour, behind a low bank of darkish-looking clouds in the northern horizon, a long bank of ashy, leaden-hued, ominous clouds began to appear, and rose higher in the sky. In a brief space of time the whole of the sky was overcast, and a darkness quickly followed so great as to render gas necessary in reading the morning newspaper. It was remarked at the time that the darkness lasted three or four times longer than is usually the case with the darkness which is observed immediately to be followed by a complete change of wind. When it passed away, the wind had changed from south-west to north-north-east and the temperature fallen, and thereafter the wind gradually rose to a gale. On the other hand, off the Berwickshire coast the darkness was denser and more threatening, and almost simultaneously with its approach a hurricane broke out with a devouring energy which bore everything before it, and, explosively as it were, instantly rose to a height which, judging from actual facts related by the fishermen who escaped and the spectators on the shore, can perhaps only be paralleled in this country in recent years by the Edinburgh hurricane of January 24, 1868. On land many lives were lost in London and elsewhere, and in all parts of the country chimney-stacks, roofs, and walls were blown down, telegraph lines were wrecked, and tens of thousands of the finest trees were snapped asunder and levelled with the ground. When there has been time to collect the records of this storm, it will be found to have been one of the most destructive to life and property in these islands in the memory of the present generation.

\section{THE INTERNATIONAL EXHIBITION AND CONGRESS OF ELECTRICITY AT PARIS ${ }^{1}$}

IV.

$A S$ we believe our readers will be interested in a fuller description of the arrangements for the telephonic hearing of the Opera than we have yet given, we extract the following from Nos. 50 and $5 \mathrm{I}$ of the new and popular French electrical journal, La Lumière Électrique, edited by Count Du Moncel. It is from the pen of the Count 